\title{
RESEARCH PAPER \\ Approximation of the surface of gypseous soils in San Luis Potosí, Mexico
}

\author{
Juan F. Martínez-Montoya ${ }^{1}$, Juan Herrero-Isern², Jorge Aceves-de Alba ${ }^{3}$, \\ Jorge Palacio-Núñez ${ }^{1}$, Víctor M. Ruiz-Vera ${ }^{1}$, and Genaro Olmos-Oropeza ${ }^{1}$ \\ ${ }^{1}$ Colegio de Postgraduados. Iturbide 73, 78620, Salinas de Hidalgo, San Luis Potosí, Mexico. \\ ${ }^{2}$ Estación Experimental de Aula Dei, Consejo Superior de Investigaciones Científicas, Apartado 13034, \\ 50080 Zaragoza, Spain. \\ ${ }^{3}$ Facultad de Ingeniería, Área Ciencias de la Tierra, Universidad Autónoma de San Luis Potosí, Manuel \\ Nava 8, 78290, San Luis Potosí, Mexico.
}

\begin{abstract}
J.F. Martínez-Montoya, J. Herrero-Isern, J. Aceves-de Alba, J. Palacio-Núñez, V.M. RuizVera, and G. Olmos-Oropeza. 2012. Approximation of the surface of gypseous soils in San Luis Potosí, Mexico. Cien. Inv. Agr. 39(3): 545-556. The gypseous soils of San Luis Potosí State, México, are not well map-delimited, despite their broad extent and the specific agricultural and environmental management they require. The present article highlights the location and extent of the gypseous lands in the Altiplano and Zona Media of San Luis Potosí State. For this purpose, soil, geology and vegetation maps as well as studies related to gypsum-rich soils, aerial photographs, and satellite maps (termed 'espaciomapas' in Spanish, these refer to Landsat-5 Thematic Mapper images of Red-Green-Blue:432 composition printed at 1:250,000 scale) were reviewed. Additionally, field and laboratory work were carried out. The maps provided by the Commission for Studies of the National Territory (CETENAL) proved very useful during the mapping process, especially as an initial reference to the presence of this soil type. The gypseous surface extent $(397,258 \mathrm{ha})$ delineated in this study is double that $(193,907 \mathrm{ha})$ reported in the CETENAL cartography at 1:50,000 scale. Moreover, areas with shallow gypsum, i.e., a gypseous horizon occurring at a depth of less than $50 \mathrm{~cm}$, were discriminated from areas with deep gypsum (termed shallow and deep gypsum phases, respectively). This distinction between shallow and deep gypsum phases is very useful for resource management planning. The maps produced serve as a reference for specific studies aimed at evaluating the suitability of land for production or environmental purposes at large scales, in which case more detailed mapping will be required.
\end{abstract}

Key words: Cartography, Landsat images, sustainable land use, photo interpretation.

\section{Introduction}

Gypseous soils (gypsum: $\mathrm{CaSO}_{4} \cdot 2 \mathrm{H}_{2} \mathrm{O}$ ) are common in the arid and semiarid lands of México and have been reported in the Chihuahan (Grande et al., 1967;

Received January 16, 2012. Accepted July 16, 2012. Corresponding author.vmanuel@colpos.mx
García, 1968; CETENAL, 1975; Meyer et al., 1992; Consejo de Recursos Minerales-CRM-, 1992) and Sonoran (Ortlieb and Pierre, 1981) deserts. The surface of these soils is currently not well known. In San Luis Potosí (SLP), the extent of gypseous soils is approximately 96,000 ha in the Altiplano and 97,000 ha in the Zona Media according to the cartography (scale 1:50,000) of the Commission for 
Studies of the National Territory (CETENAL, 1975). Prior fieldwork, aided with aerial photographs and satellite images, indicated a greater gypseous area. Existing maps were developed using information obtained almost 40 years ago; furthermore, the legend used (FAO, 1968) is currently obsolete. In some areas, there are omissions as well as execution mistakes in the mapping of gypseous soils. Advances in soil science and remote sensing were incorporated during the updating of these maps. A cartographic generalization based on the maps of the National Institute of Stastistic and Geography (INEGI) (scale 1:1,000,000) does not consider the Gypsisols even though they can be mapped at the publishing scale $(1: 4,000,000)$; furthermore, these soils are reported in the cartography as Calcisols.

The available maps produced by CETENAL (1975) at scales of 1:50,000 and 1:250,000, INEGI (1981) at the scale of 1:1,000,000 and CRM (1992) at scales of 1:50,000, 1:250,000 and 1:1,000,000 were reviewed. Geological studies regarding gypseous areas (Urías, 1965; García, 1968; López, 1973) and studies related to the wildlife habitat (Yeaton and Flores, 2006) were also revised.
These studies, with the exception of García (1968), only mentioned the occurrence of mine-oriented gypsum outcrops; the soil is considered as sedimentary or lacustrine material, and the distribution or localization data have not been provided. Although the CETENAL maps report gypseous soils, their criteria are currently obsolete due to advances in mapping techniques and soil science that have occurred during the last 38 years. These maps use the FAO legend (1968); however, a legend based on Soil Taxonomy (Soil Survey Staff, 2010, in which these soils are classified as Gypsids) or on WRB (2007, in which these soils would be classified as Gypsisols) is currently more appropriate.

These considerations demonstrate the necessity and viability of generating and updating these maps with regard to gypsum-rich soils. Thus, the objectives of this study were to determine the localization and extent, and provide the first characterization of the gypseous soils present in San Luis Potosí State, México. This information will be useful for the sustainable management of these soils and their associated resources and for new studies regarding their morphology, behavior, microbiology, and genesis.

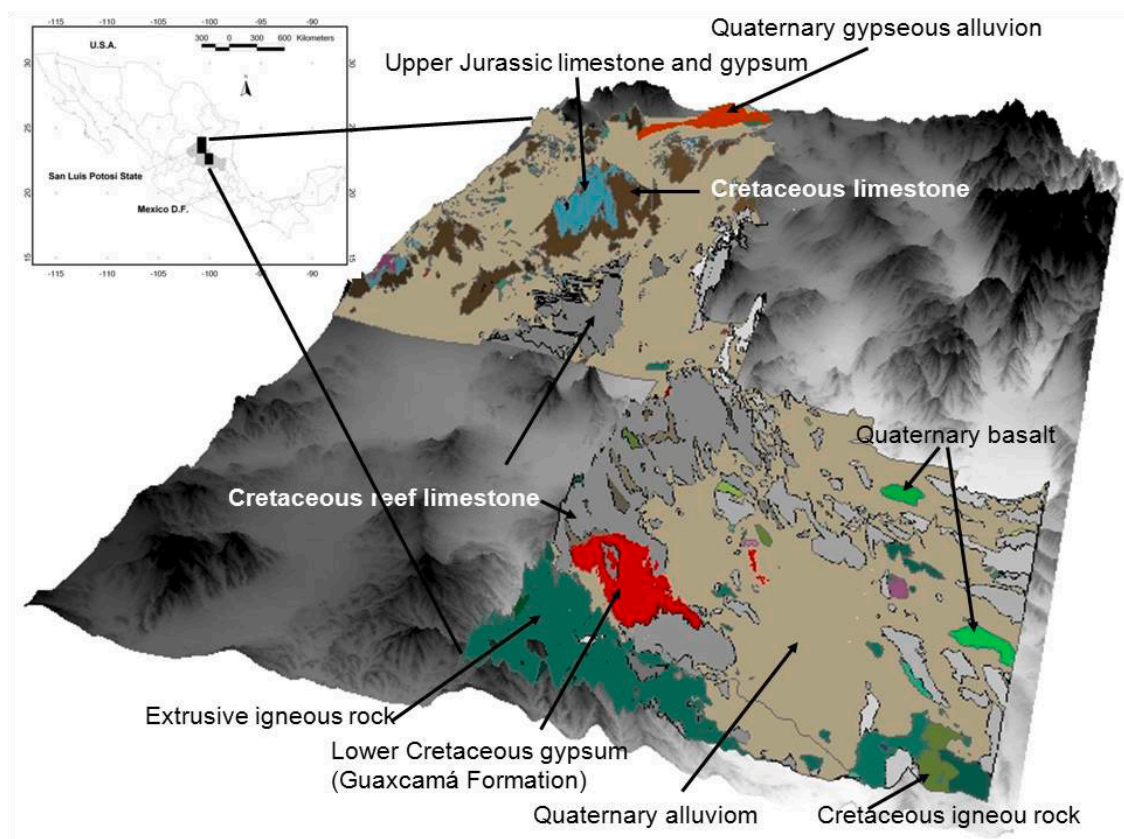

Figure 1. The study area and its associated geology (INEGI, 1981). 


\section{Materials and methods}

Study area. This study encompassed two gypseous areas in the state of San Luis Potosí, México: (i) Altiplano Potosino (200,000 ha) located between $22^{\circ} 55^{\prime}-24^{\circ} 33^{\prime} \mathrm{N}$ and $100^{\circ} 23^{\prime}-101^{\circ}$ $05^{\prime} \mathrm{W}$, and (ii) Zona Media (250,000 ha) located between $21^{\circ} 49^{\prime}-22^{\circ} 53^{\prime} \mathrm{N}$ and $99^{\circ} 40^{\prime}-100^{\circ}$ 19' W (Figure 1).

Climate. According to Köppen as adapted for México by García (1973), the Altiplano climate exhibits the driest of the dry semiarid (steppe) [BSOhw(w)] and dry arid (desert) [BW] regions. Within the Altiplano, the Salado region is the driest region $(290 \mathrm{~mm})$, and Matehuala is the moistest region $(470 \mathrm{~mm})$. The annual mean temperature ranges from 17.4 to $19.3{ }^{\circ} \mathrm{C}$ (García, 1973). The altitude varies from $1,730 \mathrm{~m}$ in the North (El Salado) to $1,320 \mathrm{~m}$ in the South (Vallejo). In the Zona Media, the climate is the moistest of the dry semiarid (steppe) [BS1hw(w)] regions. Within the Zona Media, the North region is the driest $(300 \mathrm{~mm})$ and the Cerritos - Rioverde area is the moistest $(620 \mathrm{~mm})$. The annual mean temperature ranges from 18 to $22{ }^{\circ} \mathrm{C}$ (García, 1973). The altitude varies from $980 \mathrm{~m}$ in the South (Rioverde) to $1,135 \mathrm{~m}$ in the West (Cerritos). A summer rainfall regime applies to the entire study region, and the evapotranspiration rate is three or four times that of precipitation, leading to water deficit even during the rainiest month.

Geology. In the Zona Media, the geological formations (which consist of gypsum/anhydrite, among others) are (1) Guaxcamá (this also crops out in the Altiplano) from the Berriasian-Aptian, which consists of anhydrite $\left(\mathrm{CaSO}_{4}\right)$ and gypsum with layers of dolomitic limestone (CRM, 1992); and (2) La Borreguita from the Pleistocene, in which the gypsum originates from the Guaxcamá Formation and stratiform chemical deposits are of lacustrine origin (CRM, 1992). In the Altiplano, the geological formations are (1) Yeso Minas Viejas from the Early Oxfordian, including strata of gypsum and anhydrite with lutite and sandstone (CRM, 1992;
García, 1968); (2) Olvido from the lower CallovianKimmeridgian, which is an evaporitic sequence of gypsum, anhydrite and salt (CNA, 2002); (3) Zuloaga from the Upper Jurassic; (4) La Casita from the Kimmeridgian-Tithonian, which consists of conglomerate, sandstone, lutite, limestone and gypsum (CNA, 2002); (5) "Barranca del yeso" from the start of the Albiano to the end of the Cenomanian, which constitute Gypsic strata with intercalated dolomite (Urias, 1965); (6) La Caja gypsum from the Upper Jurassic (CRM, 1992); (7) El Doctor from the Lower Cretaceous (Urias, 1965) and (8) Aluvión yesoso from the Quaternary -most likely the Holocene- (García, 1968).

Soil. The soil dates from the Holocene and most likely also the Pleistocene (CRM, 1992). The parental material originates from evaporites and precipitates of gypsum and limestone from the formations previously described and was formed in lacustrine conditions as is evident from the absence of thick fragments in the profile and the frequent accumulations of salts that are more soluble than gypsum. These alluvial soils are poorly developed with scarce amounts of clay minerals and include transport phases and a thin non-gypseous surface horizon most likely of Eolic origin. Organic matter is incorporated into the soil slowly because of the reduced microbial activity associated with low moisture levels and high temperature (Grande et al., 1967). Urias (1965) described the Altiplano soil as silty and crossed by small subcylindric tubes infilled with a whitish powder similar to plant rootlet footprints; this morphology corresponds to veniform (Grande et al., 1967) or vermiform gypsum (Herrero, 1991).

CETENAL (1975) reported the predominant Altiplano soils as Haplic, Calcic, and Gypsic Xerosols, followed by Ortic Solonchaks and Eutric Lithosols. The gypseous soils are mapped as Gypsic Xerosols (Xy) and Gypsic Yermosols (Yy), or as petrogypsic phases (layers that are strongly cemented by "calcium sulfate"-an erroneous term for gypsum-at depths of less than $50 \mathrm{~cm}$ ) or deep petrogypsic phases when such 
layers occur at depths between 50 and $100 \mathrm{~cm}$ and coinciding with other Xerosol and Yermosol soil units or subunits.

The main vegetation classes and typical species present are listed in Table 1. Mesquite woodland predominates in the Zona Media, whereas desert shrubland predominates in the Altiplano (CETENAL, 1975).

\section{The mapping of gypseous areas}

First, gypseous areas were delimited in the CETENAL maps at scales from 1:50,000 to $1: 1,000,000$, based on knowledge of the gypseous areas of San Luis Potosí State. The map units representing Gypsic Xerosols and Gypsic Yermosols, as well as superficial or deep petrogypsic phases were considered gypseous areas; the maps were digitized at the 1:50,000 scale (CETENAL, 1975) for greater precision (Figure 1). Gypseous material is recognized in the field by the naked eye as vermiform, dusty gypsum or as loose grains of gypsum. Soils that, after stirring in water and filtering, produced a milky precipitate upon reaction with acetone were considered gypseous. Additionally, geological studies were reviewed to understand the gypseous deposits, and publications regarding gypse- ous soils in general (regarding their taxonomy, vegetation, management, etc.) were analyzed to collect reference material regarding this type of soil. Previously, field trips were undertaken to known gypseous areas to become acquainted with the nature of gypseous soils.

\section{Delimitation of the probable and final gypseous area}

The probable gypseous area (Figures 2 and 3) was determined by interpreting photographs of gypseous areas; based mainly on the tone and photographic texture, the known gypseous areas were extrapolated to adjacent areas with similar photographic characteristics. Photographs from 1967 and 1969 at the scale of 1:50,000, which covered almost $60 \%$ of the area, were used for the Zona Media; likewise, photographs from 1967 at the scale of $1: 50,000$, which covered $55 \%$ of the study area, were used for the Altiplano. Photographs at the scales of 1:25,000 and 1:75,000 (from flights undertaken during 1995 and 1996) were used for some areas not covered at the 1:50,000 scale. Photographic interpretation was conducted using a Zeiss ${ }^{\circledR}$ mirror stereoscope, and the restitution was conducted using a Zeiss ${ }^{\circledR}$ transfer scope; the topographic CETENAL map $(1: 50,000)$ was used as the base map.

Table 1. Main vegetation types and typical species found in the gypseous areas of San Luis Potosí, México (CETENAL, 1975).

\begin{tabular}{|c|c|}
\hline Vegetation Type & Main species \\
\hline Desert Shrubland & $\begin{array}{l}\text { Larrea tridentata (Moc. \& Sessé ex D. C.) Coville, Flourensia cernua D. C., Celtis pallida Torr., Acacia } \\
\text { farnesiana (L.) Willd, Prosopis laevigata (Willd.) M. C. Johnst., and Acacia amentacea D. C. }\end{array}$ \\
\hline Izotal & Yucca filifera Chabaud, Y. dicipiens Trel., and Y. carnerosana (Trel.) McKelvey. \\
\hline Mesquite Woodland & $\begin{array}{l}\text { Prosopis sp., Maytenus phyllantoides Benth. (present only in saline areas of the Zona Media), Opuntia sp. } \\
\text { Celtis pallida Torr., Koeberlinia spinosa Zucc., Atriplex canescens (Pursh) Nutt., Suaeda mexicana Gray, } \\
\text { and S. nigrescens I. M. Johnston. }\end{array}$ \\
\hline Grassland & $\begin{array}{l}\text { Gypsophile plants: Bouteloua chasei Sw, Muhlenbergia purpusii Mez, M. villiflora A. S. Hitchc, } \\
\text { Muhlenbergia villiflora var villosa (Swallen) C. W. Morden, M. porteri Scribner ex Beal, Sporobolus } \\
\text { airoides (Torr.) Torr., Flaveria anomala B.L. Rob, F. oppositifolia (D. C.) Rydb., and Dichranocarpus } \\
\text { parviflurus Gray. }\end{array}$ \\
\hline
\end{tabular}


Satellite maps were interpreted for those areas that were not covered by aerial photographs $-45 \%$ in the Altiplano and $40 \%$ in the Zona Media- (Figure 2). The external boundaries of the maps based on photographic interpretation corresponding to the boundaries of the prospected gypseous area were transferred based on gypseous areas having light, bluish or gray-green tones and by the relief. These areas on the map were termed probable gypseous areas because gypseous areas were found during the field trips in areas that were not reported as such in literature maps, and other areas were found to be not gypseous; thus, field verification was required. Probable gypseous areas (zones with a high probability of being gypseous) and less probable gypseous areas (zones with a lower probability of being gypseous

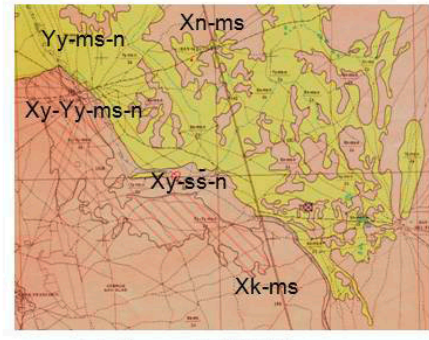

a) Soil map, CETENAL.

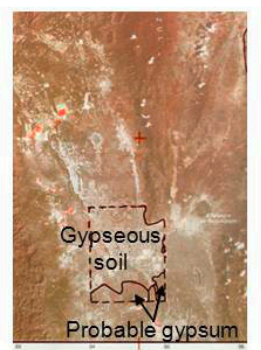

c) Delineation on photographs transferred to the espaciomapas
$\mathrm{Xn}=$ Natric Xerosols $\mathrm{Xy}=$ Gypsic Xerosols $\mathrm{Xk}=$ Calcic Xerosols Yy=Gypsic Yermosols Phases $\mathrm{ms}=$ Moderately saline ss=Strongly saline $\mathrm{n}=$ Sodic

(1)

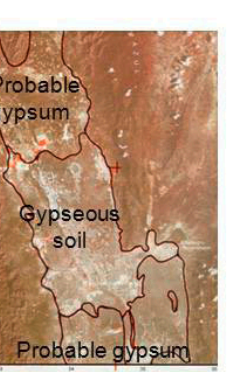

d) Map of probable gypsumarea.

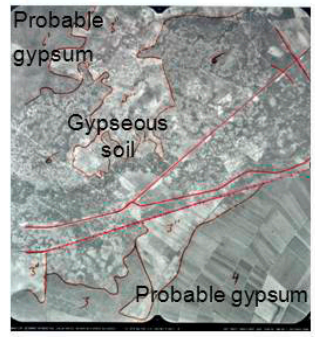

b) Photointerpretation.

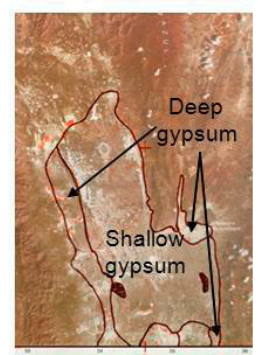

e) Map of final gypseous area.

Figure 2. The procedure used to obtain the map of the gypseous area based on CETENAL maps, aerial photography, satellite maps, and field and laboratory work.

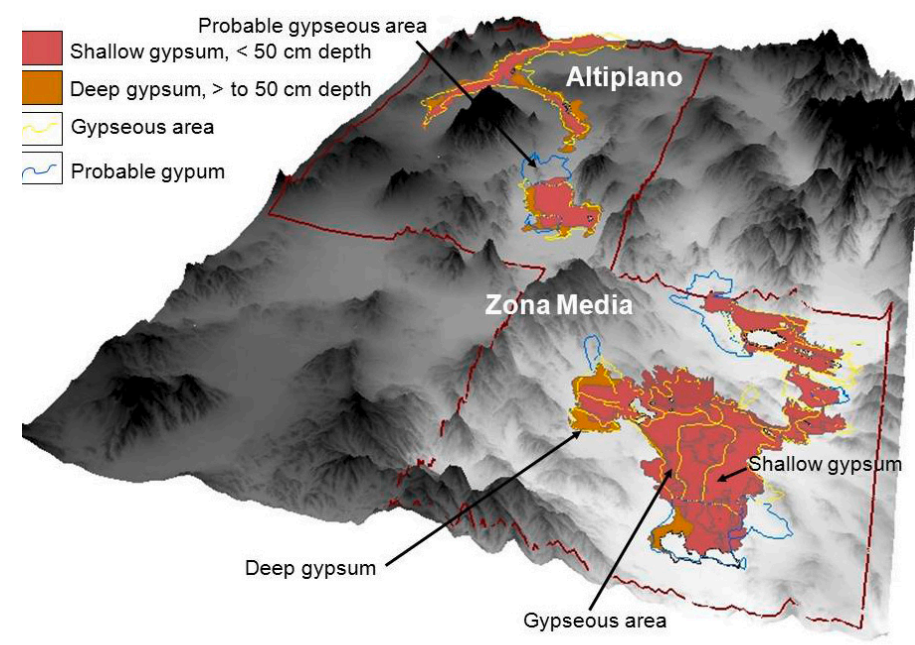

Figure 3. Probable and final gypseous areas. 
(Figure 3) were mapped. During this phase of the study, the satellite map was used as the base map, and the final map was the 1:50,000 topographic map. In this way, the complete probable gypseous area was delimited (including the gypseous area reported by CETENAL) in the satellite maps and part of the same probable gypseous area was delimited using aerial photographs.

\section{Cartographic verification}

Maps of geology, vegetation and soil use, topography, and probable gypseous area as well as aerial photographs (García, 1968; CETENAL, 1975) were used for field verification. Fieldwork was conducted (the trips were conducted in transects according to the accessibility and the need for detecting gypseous areas) to compare the boundaries. To correct the boundaries, the boundaries were labeled and tentatively relocated in the satellite map and in the aerial photographs. The final delineation of boundaries was based on office-work using new photographic interpretation and visual analysis of the space map. It was considered convenient to divide the gypseous area according to the depth at which the gypseous horizon appears. Thus, the cartographic units of shallow gypsum (a shallow phase, gypseous horizon in the first $50 \mathrm{~cm}$ ) and deep gypsum (a deep phase, gypseous horizon at a depth of greater than $50 \mathrm{~cm}$ ) were generated. Soils of the shallow horizon and, sometimes, the underlying horizon did not produce white precipitate when mixed with acetone. The delineation based on the satellite maps, corresponding to the areas for which aerial photographs were not available, were transferred by hand considering the relief, tones, texture, road system, villages, verification points and other landmarks. The results were digitized using the program CartaLinx v. 2 from IDRISI; the surface was obtained, edited, and printed using ARCVIEW v 3.2 .

The following data were taken at each georeferenced site (Garmin XL3 GPS): a) ant and small rodent activity, mainly in soils with a dark surficial horizon mapped by CETENAL as Vertisol; b) the presence of gypsophile plants (Table 1); c) doline presence; d) Cynomys mexicanus (prairie dog) activity, the habitat of which is the gypseous area (Yeaton and Flores, 2006); and e) the presence of a gypseous horizon was recorded at each site Additionally, the following activities were undertaken: a) interviews with local farmers regarding the occurrence of gypseous material and the presence of tunnels ("abras" in Spanish) in the irrigated land; b) the identification of places where "cuartones" (gypsum bricks) are extracted for use as building material; and c) visits to open-pit gypsum extraction mines (quarries), such as "La Borreguita" and "Don Pedro".

When needed, the first meter of soil depth was explored. In the Zona Media, 158 verification sites were explored, and 139 sites were explored in the Altiplano. The sites were verified from April to December, 1999, and during January-February, July and September-November, 2000.

Soil samples were taken (130 in the Zona Media and 116 in the Altiplano) from the gypseous horizon and from sites where confirmation of the gypseous composition of the soil was required, i.e., when the presence of gypsum was in doubt.

The soil was not sampled when gypsum was evident. The soil samples were analyzed to determine the gypsum presence as follows: 100 $\mathrm{mL}$ of water were added to $10 \mathrm{~g}$ of soil, $10 \mathrm{~mL}$ of acetone were added after shaking and filtration. The appearance of a milky precipitate was considered a positive reaction. Annotations were made for each site regarding land conditions and the type of vegetation present and, when possible, plant samples were collected. The boundaries of the material rich in gypsum were corrected based on the field and laboratory information, and on a new photographic interpretation. In this way, the final map of the gypseous area was obtained, comprising two map units according to the depth of gypsum occurrence (Figure 3). 
After the cartography of the gypseous areas had been verified based on geomorphology, climate, geology, vegetation, landscape and prairie dog (Cynomys mexicanus) colonies, 16 pits were localized and described (11 in the Zona Media and 5 in the Altiplano). Physical and chemical analyses were conducted according to Van Reewijk (1999). According to Soil Survey Staff (2010) the pedions are classified as Typic Petrogypsids (2), Leptic Haplogypsids (7), Typic Calcigypsids (3), Calcic Petrogypsids (2), Sodic Haplogypsid (1), and Typic Haplogypsid (1); according to the World Reference Base for Soil Resources (WRB, 2007), the pedions are classified as Epipetric Gypsisols (3), Hypergypsic Gypsisols (5), Gypsic Kastanozems (3), Orticalcic Gypsisols (1), Sodic Solonchaks (1), Gypsic Solonchaks (1), Episalic Gypsisols (1) and Endopetric Gypsisols (1).

\section{Results and discussion}

The map of gypseous land, obtained from the CETENAL maps (1975) at 1:50,000 scale, are shown in Figure 1; the map of the probable and updated gypseous zone is presented in Figure 3. The gypseous soils reported by CETENAL (Figure 1) are distributed on the surface shown in Table 2. In both zones (the Zona Media and the Altiplano), the following soils dominate: Gypsic Xerosols, Ortic Solonchaks, Haplic Xerosols and Calcic Xerosols. The last three soils have a shallow or deep petrogypsic phase. In the Zona Media, Pellic Vertisols and Calcic Kastanozems occur; this contrasts with the Altiplano, where both of these soils are absent. Gypsic Yermosols do not appear in the cartography of the Zona Media. This soil, together with the greater presence of Xerosols, is an indication of the greater aridity of the Altiplano.

Table 2. Areas (ha) by soil type at the scale of 1:250,000 (INEGI, 1981) for areas reported by CETENAL (1975) as gypseous and non-gypseous at the scale of 1:50,000.

\begin{tabular}{|c|c|c|c|c|}
\hline \multirow[b]{2}{*}{ Soil } & \multicolumn{2}{|c|}{ Zona Media } & \multicolumn{2}{|c|}{ Altiplano } \\
\hline & Non-gypseous & Gypseous & Non-gypseous & Gypseous \\
\hline Calcic Kastanozems & $5,572.5$ & $8,996.7$ & $8,399.7$ & \\
\hline Haplic Kastanozems & & & $1,651.9$ & \\
\hline Calcic Chernozems & $28,181.0$ & & & \\
\hline Haplic Phaeozems & $1,331.3$ & & & \\
\hline Calcaric Phaeozems & 271.4 & & & \\
\hline Calcaric Fluvisols & 284.1 & & & \\
\hline Calcaric Gleysols & & & 395.7 & \\
\hline Eutric Litosols & $3,408.3$ & $8,000.3$ & 409.7 & $1,998.7$ \\
\hline Eutric Regosols & 9.8 & & & \\
\hline Calcaric Regosols & $4,287.5$ & & 344.9 & \\
\hline Rendzina & 293.7 & & $6,957.9$ & \\
\hline Ortic Solonchaks & $12,763.9$ & $29,301.1$ & $19,515.3$ & $18,169.7$ \\
\hline Mollic Solonchaks & & & 405.9 & \\
\hline Gleyic Solonchaks & & 94.7 & & \\
\hline Pellic Vertisols & $10,330.7$ & $3,741.9$ & & \\
\hline Chromic Vertisols & $3,420.5$ & & & \\
\hline Calcic Xerosols & $20,193.8$ & $11,418.8$ & $23,525.0$ & 848.6 \\
\hline Gypsic Xerosols & $7,654.0$ & $105,141.8$ & $17,299.5$ & $61,701.2$ \\
\hline Haplic Xerosols & $9,103.5$ & $15,869.2$ & $15,355.6$ & $4,783.2$ \\
\hline Luvic Xerosols & & & $2,114.7$ & \\
\hline Gypsic Yermosols & & $8,834.0$ & 468.1 & $8,834.0$ \\
\hline Haplic Yermosols & & 509.0 & & 509.0 \\
\hline Total & $107,106.0$ & $19,1907.5$ & $96,843.9$ & $96,844.4$ \\
\hline
\end{tabular}


The surface area of gypseous soils found in this study is twice that reported by CETENAL (1975) at the scale of 1:50,000 for both regions $(96,000$ ha in the Altiplano and 97,000 ha in the Zona Media). A total gypseous area of 397,259 ha was delimited; in contrast, CETENAL reported an area of 193,907 ha, equivalent to $48.8 \%$ of the surface mapped in the present study. Per region, the gypseous area mapped by CETENAL represents $47.5 \%$ of the gypseous land in the Zona Media and 50.2\% in the Altiplano (Figures 1 and 3, and Table 2). The CETENAL map underestimates the surface area of gypseous soils because it only considers Gypsic Xerosols and Gypsic Yermosols (FAO, 1968), and other soils with petrogypsic phase; it does not recognize several gypseous areas. The reason is that these documents use a legend (FAO, 1968) that is currently obsolete; of course, no better option was available when the CETENAL map was constructed. In the present study, new gypseous areas were found that had not been reported previously by Urías (1965), López (1973), or CRM (1992). Instead, gypseous areas with gypseous soils are mapped by CRM as alluvial material. Other lithological studies reported the gypseous soil as gypsum outcrops (CRM, 1992), gypseous sediments, alluvial or lacustrine sediments (López, 1973), or as alluvial sediments from the Quaternary with high gypsum content (García, 1968). Furthermore, the cartographic units reported by García are not continuous in other maps as they are in the CETENAL cartography.

CETENAL reported gypsum in some areas where does not exist or is very scarce, e.g., the travertine area around Rioverde and Progreso, in the Zona Media. These areas are confused with areas containing gypsum because the photographic interpretation pattern is very similar to that of gypseous areas; only fieldwork or the qualitative determination of gypsum proved its presence or absence. The confusion is explained, partially, by the presence of local gypsum outcrops (sometimes several square meters in size) in the travertine zones. The confusion may also arise from the presence of areas with scarce vegetation.
CETENAL included some areas with lutite as gypseous surface, e.g., near the village of Rancho Nuevo, Matehuala. Nevertheless, the cartography of CETENAL was very important to us in localizing, recognizing, and delineating gypseous land because it permitted us to understand these soils and become familiar with them despite the current lack of soil scientists who are expert in gypsumrich soils in México. In addition, the CETENAL maps were very useful as a starting document to investigate possible gypseous areas, thereby saving time, resources, and field and laboratory work. Without this information, it would not have been possible to obtain our results in the time taken and using the same methods. These maps, also, will save resources (time, field and laboratory work, etc.) while updating the cartography of gypseous areas.

The predominance of areas with shallow gypsum (92.5\% in the Zona Media and 69\% in the Altiplano) is highlighted in Table 3. The gypseous surface reported is not definitive, as personal references have been made regarding the existence of gypseous materials in other parts of the state, e.g., in the municipality of Charcas in the Altiplano (Pablo Pineda Mares, personal communication) or an area (90 ha) of outcropping gypsum in "Barranca del Yeso". On the other hand, the gypseous area in the final map covered a smaller area than that in the initial map because several areas were initially confused with gypseous areas due to their characteristics. Thus, areas with a petrocalcic horizon exposed by erosion, areas with surficial travertine or lutite, areas with seal or crust, and areas with low vegetal covering showed interpretation patterns similar to those of gypseous soils in both aerial photographs and satellite maps (e.g., color, tone, and texture).

Similarly, gypseous zones pertaining to the states of Nuevo León and Tamaulipas were included in the initial map. In addition, almost all of the surface area of the cartographic unit termed "less probable gypseous area" was not gypseous; this was the case north of the village of El Carmen, 
Table 3. Gypseous land reported by CETENAL and the final gypseous land found in this study.

\begin{tabular}{lcccc}
\hline & CETENAL & \multicolumn{3}{c}{ Final gypseous land, ha } \\
\cline { 3 - 5 } Region & ha & Deep phase & Shallow phase & Total \\
\hline Zona Media & 96,844 & 15,287 & 188,663 & 203,950 \\
Altiplano & 97,063 & 59,856 & 133,453 & 193,309 \\
Total & 193,907 & 75,143 & 322,116 & 397,259 \\
\hline
\end{tabular}

Villa de Guadalupe, in the Altiplano. In general, the method followed in this study enabled the cartography of the gypseous areas of San Luis Potosí state to be updated; the final gypseous surface is double that marked in current cartography at the scale of 1:50,000 (from 193,907 to 397,258 ha). Field and laboratory work allowed identification of gypseous areas not included in the current edaphological cartography and other areas that had previously and erroneously been reported as gypseous. These maps of the gypseous areas will be useful as a reference for specific studies aimed at evaluating the aptitude of the land for production purposes, which requires more detailed cartography and the delimitation of areas where Gypsic or shallow Petrogypsic horizons are present, as well as areas that are more homogeneous.

Regarding the gypseous area, the map shown in Figure 3 can be considered as reconnaissance; the map is considered within the limits of the semidetailed studies given the material used and the field and laboratory work. Additionally, attributes of viability were contemplated, considering the general area as used for livestock (or of agricultural use, in some parts). The degree of performance, according with the objective and use of teledetection and field information, correspond to the level of study. For cartography to be useful at a scale corresponding to a plot or experiment, cartographic units should be delineated at the level of consociation, which requires more laboratory and field work; such delineation would permit the use of the maps for management plans and evaluating capacity use. Considering the density of observations recorded, the obtained maps correspond to a reconnaissance level on a scale of $1: 175,000$ and with a tolerance in the location of the boundaries of $175 \mathrm{~m}$.
The predominant soils in the Altiplano, at the scale of 1:250,000 (INEGI, 1981), in areas not delimited as gypseous (at the scale of 1:50,000) by INEGI (Table 2), are Calcic Xerosols, Ortic Solonchaks, Haplic and Gypsic Xerosols. In the Zona Media, this area corresponds mainly to Calcic Chernozems, Calcic Xerosols, and Ortic Solonchaks. Note that the Calcic Chernozems, Haplic and Calcaric Feozems, Calcaric Fluvisols, Eutric Regosols, and Pellic and Chromic Vertisols are not delimited in the Altiplano; similarly, the Haplic Kastanozems, Calcaric Gleysols, Mollic Solonchaks, Luvic Xerosols, and Gypsic Yermosols are not present in the Zona Media. The data shown in Table 2 imply that the gypseous surfaces are delimited differently on different scales (1:250,000 or 1:50,000); thus, at the scale of $1: 250,000,7,654$ ha of gypseous soils are present in the Zona Media and 17,767 ha of gypseous soils are present in the Altiplano that are not recognized as gypseous at the scale of 1:50,000. Furthermore, the total surface areas considered as gypseous at the scale of 1:50,000 are 55,804 and 69,561 ha for the Zona Media and Altiplano, respectively; these areas are lower than those measured at the scale of 1:50,000 (Table 3).

The FAO legend from 1968, which is now obsolete, considered the Gypsic or Petrogypsic horizons at the phase level. Later, FAO (1988) introduced the concept of Gypsisols, which is maintained in the WRB (2007), as a reference soil or as a unit for other soils at a lower level. Additionally, other concepts and terms related to gypsum have been introduced, such as the hypergypsic horizon (WRB, 2007). The taxonomic role of gypsum in Soil Taxonomy was recognized several years after the publication of the CETENAL maps. Soils with Gypsic horizons were previously classified as Calcic Camborthids or Calcorthids in the 
Seventh Approximation (Soil Survey Staff, 1960). The first edition of Soil Taxonomy (Soil Survey Staff, 1975) denominates Gypsiorthids as soils with gypsum at the level of Great Group. Later, when the order Aridisols was reorganized, the Suborder Gypsids was created. The tenth edition of the keys (Soil Survey Staff, 2010) provides a scheme for the classification of Gypsids that also uses Gypsic and Petrogypsic horizons in other taxonomic categories. The mentioned taxonomic advances permit classification of the gypseous soils of San Luis Potosí as Gypsids according to Soil Survey Staff (2010) or denominate these soils as Gypsisols according to WRB (2007). Analogously, cartographic techniques based on satellite imagery can be used to update the gypseous lands of México.

Table 4 shows the gypseous surface affected by salts or sodium according to INEGI cartography at the scale of 1:250 000. Thirty-six percent of the surface in the Zona Media and 39\% of the surface in the Altiplano have some salinity problem. In the Zona Media, strongly saline and strongly sodic conditions predominate, followed by (in order of importance) sodic and saline-sodic conditions. In the Altiplano, problems are caused by the sodic and saline conditions. Generally, sodic (21\%), strongly saline-strongly sodic $(10.5 \%)$, and saline $(4.8 \%)$ soil conditions predominate and comprise a total of
144,200 ha. The data presented in Table 4 and the results of the field verification indicate the importance of knowing these parameters for the study zone, especially when establishing a new irrigated area or improving management of an existing irrigated area; knowledge of these parameters allow management to be planned in a more appropriate way with respect to soil characteristics. Additionally, not all of the gypseous surface is reported in the existing cartography, and the importance of soluble salts or sodium has been demonstrated in both areas of study during the field work. A large portion of these newly classified gypseous areas is reported as Solonchak in the CETENAL cartography, possibly because greater importance was given to salinity or sodicity than to the presence of gypsum.

For this reason, the salinity and sodicity should be considered during the planning of gypseous soil management, in addition to the high gypsum content. Furthermore, when new irrigation areas are established or existing irrigated areas are improved, the gypsum content and the depth at which the Gypsic or Hypergypsic horizon is found should be considered with respect to soil management. Drip or sprinkler irrigation should be chosen rather than flood irrigation (this is also true for plasticulture); the subsidence risk would thus be lower, especially in areas with shallow Gypsic horizons.

Table 4. Land affected by soluble or sodium salts (scale 1:250,000) (INEGI, 1981).

\begin{tabular}{|c|c|c|c|c|c|c|}
\hline \multirow[b]{2}{*}{ Chemical phase } & \multicolumn{2}{|c|}{ Zona Media } & \multicolumn{2}{|c|}{ Altiplano } & \multicolumn{2}{|c|}{ Total } \\
\hline & ha & $\%$ & ha & $\%$ & ha & $\%$ \\
\hline Saline & $2,059.3$ & 1.0 & $16,863.3$ & 8.3 & $18,922.6$ & 4.8 \\
\hline Sodic & $21,687.2$ & 10.6 & $61,803.5$ & 30.3 & $83,490.7$ & 21.1 \\
\hline Saline - Sodic & $5,840.3$ & 2.9 & 22.5 & 0.1 & $5,862.8$ & 1.5 \\
\hline Strongly Saline & $2,243.8$ & 1.1 & & & $2,243.8$ & 0.6 \\
\hline Saline - Strongly Sodic & & & $1,996.6$ & 1.0 & $1,996.6$ & 0.5 \\
\hline Strongly Saline - Sodic & 123.0 & 0.1 & & & 123.0 & 0.1 \\
\hline Strongly Sodic & & & $2,359.4$ & 1.2 & $2,359.4$ & 0.6 \\
\hline Strongly Saline - Strongly Sodic & $41,787.4$ & 20.5 & & & $41,787.4$ & 10.5 \\
\hline Total & $73,741.0$ & 36.2 & $83,045.3$ & 40.9 & $156,786.3$ & 39.7 \\
\hline
\end{tabular}

Salinity: low $=1.1-2.0$, moderate $=4.1-8$, strong $=8.1-16$, very strong $\geq 16 \mathrm{dS} / \mathrm{m}$. Sodicity: Sodic $=15-40$, strongly sodic $>40$ Exchangeable Sodium Percentage. 


\section{Resumen}

J.F. Martínez-Montoya, J. Herrero-Isern, J. Aceves-de Alba, J. Palacio-Núñez, V. M. Ruiz-Vera y G. Olmos-Oropeza. 2012. La extensión de los suelos yesosos en San Luis Potosí, México. Cien. Inv. Agr. 39(3): 545-556. Los suelos yesosos del Estado de San Luis Potosí no están bien delimitados pese a ocupar extensiones considerables y requerir un manejo agrícola y ambiental específico. En este trabajo se indaga la localización y extensión de la superficie yesosa en el Altiplano y Zona Media del Estado de San Luis Potosí, México. Para ello se consultó información cartográfica de suelos, de geología y de vegetación, así como estudios relacionados con suelos ricos en yeso; además, se usaron fotografías aéreas, espaciomapas (imágenes Landsat-5 Thematic Mapper en composición Rojo-Verde-Azul: 432 impresas a escala 1:250000), y se llevó a cabo trabajo de campo y de laboratorio. Los mapas de la Comisión de Estudios del Territorio Nacional fueron de gran ayuda en el proceso de cartografía, sobre todo como referencia inicial de la presencia de materiales yesosos. La superficie yesosa delimitada en el presente estudio (397.258 ha) duplica la reportada (193.907 ha) en la cartografía de la Comisión de Estudios del Territorio Nacional a escala 1:50.000. Además se discriminaron áreas con yeso somero, es decir, con horizonte yesoso a menos de $50 \mathrm{~cm}$ de profundidad, y áreas con yeso profundo. Esta discriminación entre fase somera y fase profunda es muy útil para planear el manejo de estos suelos. Los mapas generados sirven como referencia para estudios específicos, encaminados a evaluar la aptitud de la tierra con fines productivos o de protección ambiental a escalas grandes, en cuyo caso debería levantarse cartografía más detallada.

Palabras clave: Cartografía, imágenes Landsat, uso sustentable, fotointerpretación.

\section{References}

CETENAL. 1975. Cartografía temática. CETENAL (Comisión de Estudios del Territorio Nacional). Secretaría de Programación y Presupuesto (SPP), México, D.F.

CNA. 2002. Determinación de la disponibilidad de agua en el acuífero Tula-Bustamante, estado de Tamaulipas. CNA (Comisión Nacional del Agua). México, D.F. 12 pp.

CRM. 1992. Monografía Geológico - Minera del Estado de San Luis Potosí. Publicación M-7e. Serie: Monografías Geológico Mineras. Secretaría de Energía, Minas e Industria Paraestatal, Subsecretaría de Minas e Industria Básica. CRM (Consejo de Recursos Minerales), Gobierno del Estado. 218 pp.

FAO - Food and Agriculture Organization of the United Nations. 1968. Clave de unidades de suelos para el mapa de suelos del mundo. FAO (Organización de las Naciones Unidas para la Agricultura y la Alimentación). Roma, Italia.
FAO - Food and Agriculture Organization of the United Nations. 1988. Soil map of the world. Revised legend. World Soil Resources Report 60. FAO, Roma. Italia.

García, E. 1973. Modificaciones al Sistema de Clasificación Climática de Köppen (para adaptarlo a las condiciones de la República Mexicana). Instituto de Geografía, Universidad Nacional Autónoma de México (UNAM), México, D.F. $246 \mathrm{pp}$.

García-Calderón, J. 1968. Carta Geológica de México, Serie de 1:100 000, Hoja El Salado, 14R - j(11). Instituto de Geología, Universidad Nacional Autónoma de México, México, D. F.

Grande-López, R., X.E. Hernández, N. Aguilera, and J. Boulaine. 1967. Morfología y génesis de suelos yesíferos de Matehuala, S. L. P. Agrociencia $1: 130-147$.

Herrero, J. 1991. Morfología y Génesis de Suelos Sobre Yesos. Monografías INIA No 77. Ministerio de Agricultura, Pesca y Alimentación. Madrid, España. 447 pp. 
INEGI - Instituto Nacional de Estadística, Geografía e Informática. 1981. Síntesis Geográfica del Estado de San Luis Potosí. SPP, D. F., México. 186 pp. López-Ramos, E. 1973. Carta Geológica del estado de San Luis Potosí. 2da edición. Escala 1:500 000. Instituto de Geología de la Universidad Nacional Autónoma de México (UNAM). México, D. F.

Meyer, S.E., E. García-Moya, and L. Lagunes-Espinoza. 1992. Topographic and soil surface effects on gypsophile plant community patterns in central México. Journal of Vegetation Science 3:429-438.

Ortlieb, L., and C. Pierre. 1981. Génesis evaporítica en tres áreas supralitorales de Baja California; contextos sedimentarios y procesos actuales. Revista del Instituto de Geología, Universidad Nacional Autónoma de México 5:94-116.

Soil Survey Staff. 1960. Soil classification A Comprehensive system. $7^{\text {th }}$ Approximation. SSS (Soil Survey Staff). USDA Soil Conservation Service. U.S. Government printig Office. Washington, DC, USA. 265 pp.

Soil Survey Staff. 1975. Soil Taxonomy. Soil Conservation Service, Agriculture Handbook No 436. SSS (Soil Survey Staff). USDA. Washington, DC, USA. 754 pp.
Soil Survey Staff. 2010. Keys to Soil Taxonomy. 11 $1^{\text {th }}$ edition. Natural Resources Conservation Service. SSS (Soil Survey Staff). United States Department of Agriculture (USDA). Washington, DC, USA. 338 pp.

Urías-Rodríguez, A. 1965. Estudio Geológico de la Sierra de Guadalcázar. Folleto técnico No 8. Instituto de Geología y Metalurgia, Universidad Autónoma de San Luis Potosí (UASLP), SLP. México. 35 pp.

Van Reeuwijk, L.P. (ed.) 1999. Procedimientos para Análisis de Suelos, versión 1995. Traducción de: Gutiérrez-Castorena, Ma del C., TavarezEspinosa, C. A., and Ortiz-Solorio, C. A. Primera edición en español. Especialidad de Edafología, Colegio de Postgraduados. Montecillo, México. $145 \mathrm{pp}$.

WRB. 2007. World Reference Base for Soil Resources 2006, first update 2007. IUSS Working Group. World Reference Base (WRB). World Soil Resources Reports No. 103. FAO, Rome. 97 pp.

Yeaton, R.I., and J.L. Flores-Flores. 2006. Patterns of ocurrence and abundance in colony complexes of the Mexican prairie dog (Cynomys mexicanus) in productive and unproductive grasslands. Acta Zoológica Mexicana 22(3):107-130. 